\title{
New Hybrid Materials Synthesized with Different Dyes by Sol-Gel Method
}

\author{
Ramona Gheonea, ${ }^{1}$ Eleonora Cornelia Crasmareanu, ${ }^{2}$ Nicoleta Plesu, ${ }^{2}$ Sorin Sauca, ${ }^{3}$ \\ Vasile Simulescu, ${ }^{2}$ and Gheorghe Ilia ${ }^{1,2}$ \\ ${ }^{1}$ Faculty of Chemistry, Biology, Geography, West University of Timisoara, 4 Bv. Vasile Parvan, 300223 Timisoara, Romania \\ ${ }^{2}$ Institute of Chemistry Timisoara of the Romanian Academy, 24 Mihai Viteazul Bvd., 300223 Timisoara, Romania \\ ${ }^{3}$ Institute of Chemical Research of Catalonia, 16 Av. Paisos Catalans, 43007 Tarragona, Spain
}

Correspondence should be addressed to Vasile Simulescu; gianisimulescu@yahoo.com and Gheorghe Ilia; gheilia@yahoo.com

Received 18 May 2017; Accepted 27 July 2017; Published 28 August 2017

Academic Editor: Renal Backov

Copyright (C) 2017 Ramona Gheonea et al. This is an open access article distributed under the Creative Commons Attribution License, which permits unrestricted use, distribution, and reproduction in any medium, provided the original work is properly cited.

\begin{abstract}
One well-known method for hybrids synthesis with incorporated organic dyes is sol-gel method, which is based on the concept of molecular manipulation to design ceramics, glasses, and composites. The low-temperature process allows for the incorporation of guest organic molecules within the inorganic matrix, as well as for the synthesis of hybrid networks in which the organic and inorganic phases are interpenetrating. The aim of the work presented in this paper was the preparation of the gels with three different dyes, at different molar ratios by using the hydrolytic sol-gel process. The interaction of the dye and the oxide was examined by UV-vis spectroscopy and FT-IR. The thermal stability of the hybrid organic-inorganic xerogel formed here was studied by thermal analysis. The micrographs obtained by scanning electron microscopy (SEM) revealed the high density of the films. Such characteristics indicate the possible application of these films in solar cells.
\end{abstract}

\section{Introduction}

The sol-gel technology, by which inorganic or composite organic-inorganic materials are made at relatively low temperature, consists of hydrolysis of the constituent molecular precursors and subsequent polycondensation to glass-like form. The technology allows the incorporation of organic and inorganic additives. Based on the sol-gel process, a large number of sophisticated materials have been prepared and studied during last decades. The first successful attempt to incorporate organic dyes and to stabilize them within a solgel matrix started in 1984, by Reisfeld et al. [1-6]. The use of organic dyes in a hybrid organic-inorganic matrix has better characteristics than an organic matrix because the dye colored hybrid films have enhanced mechanical properties like higher hardness and stronger abrasion resistance [7]. With respect to inorganic sol-gel films, hybrid films also provide several advantages such as much better adhesion, transparency, flexibility, reduced surface roughness, and better refractive index matching [8-12].
Organic dye incorporated silica gels have many applications for nonlinear optical materials, laser, chemical sensors, color filters, luminescent solar concentrators, high density memories, and coating for glass bottles which can be easily recycled [13-17]. The sol-gel method is one of promising methods to prepare such materials. The concentration, coordination state, and dispersion of dye molecules in gels are important factors for optical applications. Organic dyes incorporated in inorganic silica gels by the sol-gel method are monomeric at low concentration but tend to form dimers in higher concentrated solutions [18].

The applications of the dyes include coloring textiles paper, leather, plastic, food, medicines, cosmetics, and solar and photovoltaic cells $[19,20]$. Dye-sensitized solar cells (DSSCs) are one of their main applications nowadays, which have attracted a lot of interest, as a new option in photovoltaics area (especially as potential materials for photovoltaic cells) [21-25]. Dye-sensitized solar cells are more suitable to be used at large scale in comparison with the classical 


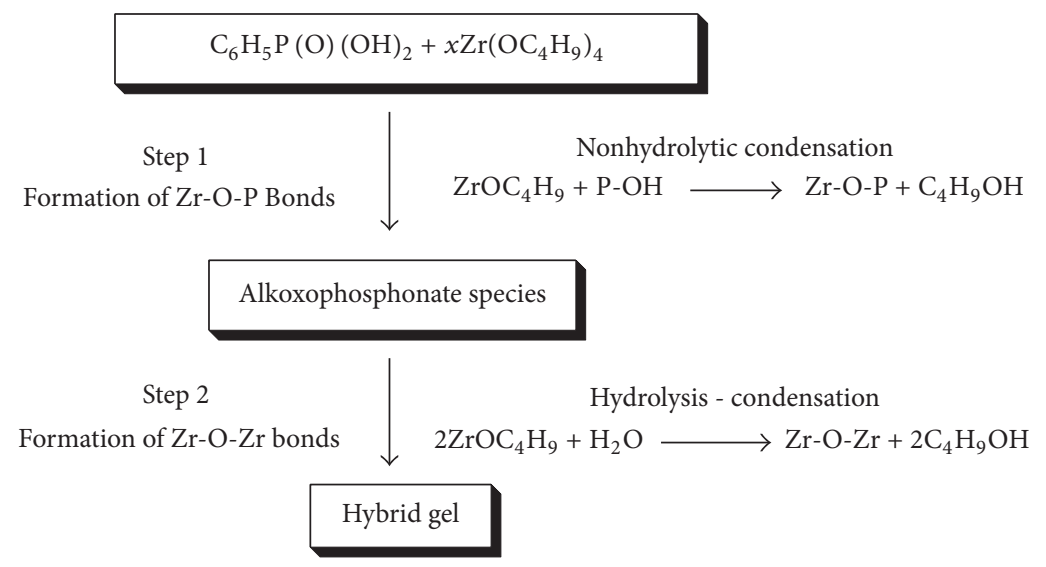

Scheme 1: Representation of the two-step sol-gel process.

photovoltaics because they are much more cheaper and easier to be prepared [24, 26, 27].

The so-called organic-inorganic hybrid nanocomposites may present properties that do not depend solely on each component individually but also on interface phenomena between these phases, which can lead to synergistic effects. For example, the sol-gel method offers a molecular-level mixing of the calcium and phosphorus precursors, in comparison with conventional methods. In most cases, phosphorus compounds-oxide, triethylphosphate, and diethylphosphite are employing as phosphorus precursors in water or organic solvents phase. Polyphosphate association to aluminium, calcium, magnesium, iron, copper, or nickel ions in aqueous solution can lead to gelation under appropriate conditions.

Incorporating organic dyes with inorganic and hybrid products, obtained through the sol-gel process (Scheme 1), allows the achievement of colored layers for optics applications such as filters, transformers of solar energy, nonlinear optics, and laser environments.

The aim of the work described here was the preparation of the gels with three different incorporated dyes, by using solgel method. The gel is a solid jelly-like material that can have properties ranging from soft and weak to hard, with a lot of potential applications, from cosmetics (e.g., gels containing hyaluronic acid for skin [28-30], shower gels, and hair gels) to solar cells and even flame retardants [31].

\section{Experimental}

2.1. Materials and Methods. Phenylphosphonic acid (PPA) was purchased from Fluka, and butyl-zirconate $\mathrm{Zr}\left[\mathrm{O}\left(\mathrm{CH}_{2}\right)_{3} \mathrm{CH}_{3}\right]_{4}$ from Sigma-Aldrich. Acids dyes chromatable added to the gels based on zirconium were synthesized in our laboratory, as follows: acid dye blue-violet chromatable (C1), acid dye green chromatable (C2), and acid dye Bordeaux chromatable (C3).

In the present work, eight syntheses (S1-S8) were performed by using the three different dyes previously mentioned (C1-C3, Figure 1), at different molar ratios, as shown in Table 1.<smiles>Cc1cc(N=Nc2ccc3ccccc3c2O)c(O)cc1[N+](=O)[O-]</smiles>

Sodium salt of acid dye blue-violet chromatable (C1)<smiles>CS(=O)(=O)c1cc(N)c2c(O)c(N=Nc3cc([N+](=O)[O-])cc([N+](=O)[O-])c3O)c([N+](=O)[O-])cc2c1</smiles>

Sodium salt of acid dye green chromatable (C2)<smiles>O=S(=O)([O-])c1ccc(O)c(/N=N/c2ccc3cccnc3c2O)c1</smiles>

Sodium salt of acid dye Bordeaux chromatable (C3)

FIGURE 1: The structures of the acid dyes chromatables used.

2.2. Sol-Gel Method. Phenylphosphonic acid (PPA) was dissolved in $10 \mathrm{ml}$ ethanol for the synthesis of S1 and S2 (over which the dyes $\mathrm{C} 1-\mathrm{C} 3$ corresponding to the syntheses S3-S8 were added) depending on the molar ratios specified in Table 1. Then, the butyl-zirconate was added also in the quantity corresponding to the respective molar ratios, under magnetic stirring at room temperature, for 1.5-2 hours. After 


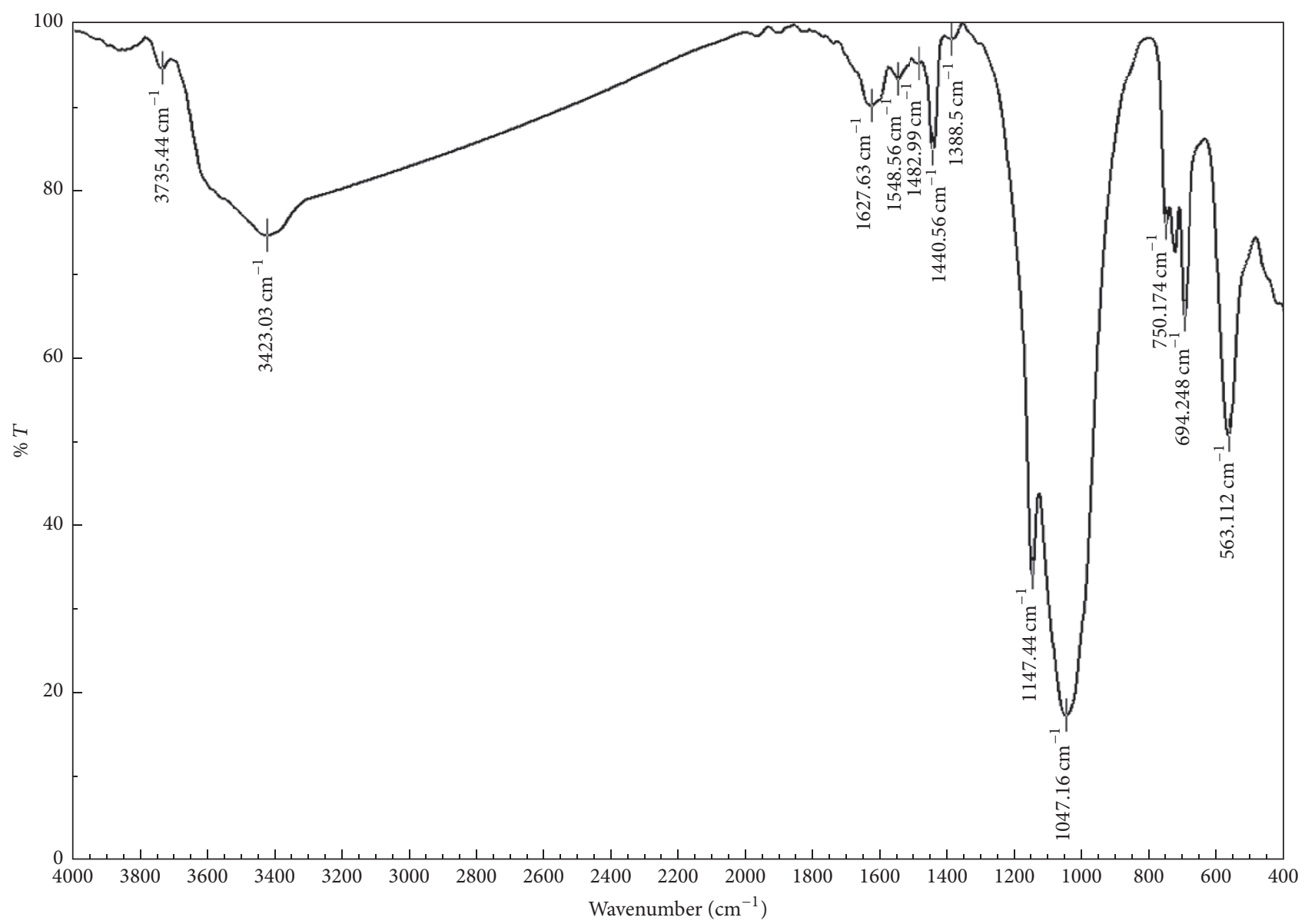

FIgURE 2: IR spectrum for compound S1 $\left(\mathrm{PPA} / \mathrm{Zr}(\mathrm{OBu})_{4}=2 / 1\right)$.

TABLE 1: The quantities of materials used corresponding to syntheses S1-S8.

\begin{tabular}{lcccc}
\hline Synthesis & $\begin{array}{c}\text { Molar ratio } \\
\text { PPA } / \mathrm{Zr}\left(\mathrm{OC}_{4} \mathrm{H}_{9}\right)_{4}\end{array}$ & $\begin{array}{c}\mathrm{C} 1 \\
\text { mmole }\end{array}$ & $\begin{array}{c}\mathrm{C} 2 \\
\text { mmole }\end{array}$ & $\begin{array}{c}\mathrm{C} 3 \\
\text { mmole }\end{array}$ \\
\hline S1 & $2 / 1$ & & & \\
S2 & $1 / 1$ & & & \\
S3 & $2 / 1$ & 0.7 & & \\
S4 & $1 / 1$ & 0.7 & & \\
S5 & $2 / 1$ & & 0.5 & \\
S6 & $1 / 1$ & & 0.5 & \\
S7 & $2 / 1$ & & & 0.7 \\
S8 & $1 / 1$ & & & 0.7 \\
\hline
\end{tabular}

two hours, the reaction mass started gelling. The obtained gel was left to dry for 2-3 days at a temperature of $40^{\circ} \mathrm{C}$ in an oven to evaporate the ethanol. The resulting compounds were further analyzed with several techniques (FT-IR, TGA, SEM, TEM, and UV-vis).

\subsection{Equipment}

(i) Jasco FT-IR 4200 Spectrometer was used for recording the IR spectra. (ii) Thermal analysis TGA-DTG-DTA (Thermogravimetry) was carried out by changing the temperature between $20^{\circ} \mathrm{C}$ and $900^{\circ} \mathrm{C}$, by using an 851-LF 1100Mettler Toledo apparatus in airflow. It has a sensitivity of $1 \mu \mathrm{g}$. The maximum amount of the sample which could be measured is $5 \mathrm{~g}$.

(iii) SEM and TEM characterizations were made using a Jeol JSM 6400 Scanning Microscope.

(iv) UV-visible spectra were recorded on a JASCO UVvis spectrometer, V-650 model (Japan). Absorption, excitations, and emission spectra were registered in environmental conditions (temperature: $20 \pm 2^{\circ} \mathrm{C}$ ), on $1 \mathrm{~cm}$ path length cells.

\section{Results and Discussion}

In Figure 2, the presence of bands near 3420, 3750, and $1627 \mathrm{~cm}^{-1}$ was assigned to asymmetric and symmetric $\mathrm{OH}$ stretching modes and physically adsorbed water, respectively, and also the absorption bands from $1540 \mathrm{~cm}^{-1}$ and $3735 \mathrm{~cm}^{-1}$ come from the vibrations of intercalated water [32]. The disappearance of the broad bands characteristic to the $v_{\mathrm{P}-\mathrm{O}-\mathrm{H}}$ vibrations in phenylphosphonic acid at $2700 \mathrm{~cm}^{-1}$ and 


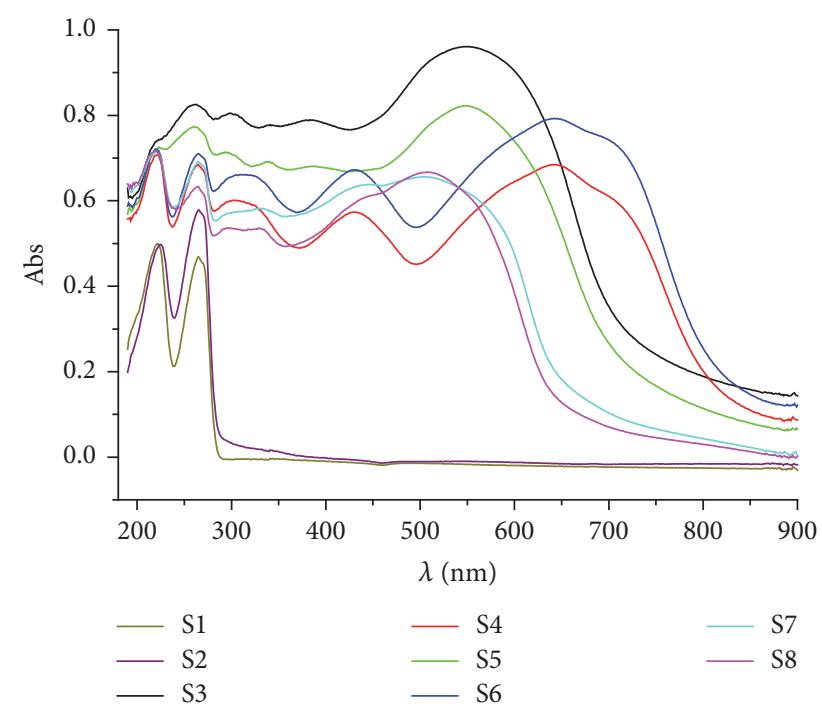

FIGURE 3: UV-vis spectra for compounds S1-S8.

$2200 \mathrm{~cm}^{-1}$ indicates the condensation of the $\mathrm{P}-\mathrm{O}-\mathrm{H}$ groups [33].

The P-O-M bands are usually broad (indicative of the delocalization of electrons) and generally fall with $900-1200 \mathrm{~cm}^{-1}$ range [34]. The formation of a P-O-M bond may be accompanied by the disappearance of the $\mathrm{P}=\mathrm{O}$ and $\mathrm{P}-\mathrm{O}-\mathrm{H}$ bonds, depending on the mode of binding, which can be mono-, bi-, or tridentate. For example, a phosphonic acid bound in tridentate form should result in just a broad band within $900-1200 \mathrm{~cm}^{-1}$ and the total disappearance of the normal $\mathrm{P}=\mathrm{O}$ and $\mathrm{P}-\mathrm{O}=\mathrm{H}$ bands. The presence of either the $\mathrm{P}=\mathrm{O}$ band or the $\mathrm{P}-\mathrm{O}-\mathrm{H}$ bands indicates the presence of mono- or bidentate binding, or a mixture of the two [35-37].

The intense band at $1047 \mathrm{~cm}^{-1}$ is assigned to asymmetrical stretching vibration of $\mathrm{P}-\mathrm{O}$ which confirms the formation of bonds $\mathrm{P}-\mathrm{O}-\mathrm{Zr}$ and the shoulder at $1150 \mathrm{~cm}^{-1}$ is ascribed to symmetrical stretching vibration of $\mathrm{P}-\mathrm{O}$ [38] from free $\mathrm{P}-\mathrm{OH}$ groups in hybrids samples. These free - $\mathrm{P}-\mathrm{OH}$ groups suggested the possibility of further condensation of $\mathrm{Ph}-\mathrm{P}-\mathrm{OH}$ species within the hybrid framework. The bands at $1388 \mathrm{~cm}^{-1}$ and $1440 \mathrm{~cm}^{-1}$ could be assigned to the characteristic bond $\mathrm{P}=\mathrm{O}$ and indicate the presence of $\mathrm{P}=\mathrm{O}$ in hybrid structure [39].

The band at $1482 \mathrm{~cm}^{-1}$ was ascribed to P-C stretching vibration which is overlapped with $\mathrm{C}-\mathrm{H}$ bending of $\mathrm{CH}_{2}$ groups [40] and one at $1627 \mathrm{~cm}^{-1}$ is due to the stretching vibration of phenylphosphonic acid. The P-C stretching modes at $1482 \mathrm{~cm}^{-1}$ and around $750 \mathrm{~cm}^{-1}$ were assigned to the presence of $\mathrm{P}-\mathrm{C}$ aromatic, observed in all hybrids.

The bands at $563 \mathrm{~cm}^{-1}$ and $694 \mathrm{~cm}^{-1}$ match well with the calculated vibration frequency of the $\mathrm{Zr}-\mathrm{O}$ species [41] and could overlap with out-of-plane $\mathrm{P}-\mathrm{OH}$ bending.

UV-vis characterization (Figure 3) was performed to determine the absorbance of the obtained hybrid materials.
From UV-vis spectra, it can be observed that, for hybrid materials S1 and S2, the maximum wavelengths values are in ultraviolet domain. The low absorption takes place at wavelengths $\lambda=222 \mathrm{~nm}$ and $\lambda=265 \mathrm{~nm}$ for $S 1$ and $\lambda=225 \mathrm{~nm}$ and $\lambda=265 \mathrm{~nm}$ for S2. This is explained by the white color of these gels. When overlapping them, it can be easily observed that they are almost identical. Only the absorbance value differs. This is due to the different molar ratio $\mathrm{PPA} / \mathrm{Zr}(\mathrm{OBu})_{4}$. In S1 and S2 UV-vis spectra, no absorbance peaks in visible domain were noticed.

In the materials in which the dyes are incorporated (S3-S8), in UV-vis spectra, the maximum wavelength values are shifted to visible range, between 505 and $643 \mathrm{~nm}$. Moreover, the curve shape is influenced by the auxochromes and chromophores substituents, grafted on basic structure of dyes. The dyes substituents showed significant influence on the obtained UV-vis spectra. The maximum absorbance was observed for hybrid S3 at $\mathrm{PPA} / \mathrm{Zr}(\mathrm{OBu})_{4}$ molar ration 2/1, followed by the hybrid S4 at PPA/ $\mathrm{Zr}(\mathrm{OBu})_{4}$ molar ration 1/1, with the same $\mathrm{C} 1$ dye. This indicates that $\mathrm{C} 1$ dye could possibly have a greater efficiency when applied to dye-sensitized solar cells (DSSC).

From the SEM images, it was concluded that the all obtained hybrids here are similar, and their morphology is amorphous and, when the dyes are present, are well dispersed. In Figure 4, SEM images of the synthesized materials S1, S4, S6, and S7 are shown.

Also, good porosity showed by hybrids S1-S8 pointed out to facile diffusion of redox mediators within the layer. This porosity is mandatory in the application in DSSC to obtain a good interaction with surface-bound dye (sensitizer). The TEM images (Figure 5) also indicate a porous structure and good dye dispersion in the hybrid framework of the obtained materials (dye molecules penetrate inside the pores).

The high percent of the macropores evidenced by TEM microscopy was confirmed by $\mathrm{N}_{2}$ adsorptions desorption.

The TG data for S1-S8 hybrids are presented in Figure 6. The TG data indicates for all hybrids a continuous weight loss till $900^{\circ} \mathrm{C}$, associated with the loss of humidity, alcohol, and oxidation of organic part of components.

In the temperature domain $25-150^{\circ} \mathrm{C}$, the weight loss is situated in the range of $4.3-6.3 \%$ and corresponds to the loss of humidity and alcohol present in sample as a result of sol-gel reaction. In the temperature range $150-350^{\circ} \mathrm{C}$, the weight loss corresponds to the release of alcohol as a result of advanced condensation process and is situated in the range of $4.4-5.8 \%$. Based on the weight loss in this stage and assuming that butyl alcohol is released, it was calculated that the second hydroxyl group from phosphonate unit could react in this stage in a proportion of maximum 35\% for S1 and 34\% for $\mathrm{S} 2$. In the case of S3-S8 sample and taking in account the dye weight loss in this step, the release of butanol as a result of second hydroxyl group reaction from phosphonate unit indicates a slightly low value than S1 and S2, about $27-32 \%$. The weight loss increased to $23.3-29.1 \%$ and is massive in the temperature domain $350-550^{\circ} \mathrm{C}$ as a result of oxidation of organic part of components and finalization of second hydroxyl group condensation with the release butyl alcohol. In $350-550^{\circ} \mathrm{C}$, the phenyl group is principally susceptible to 


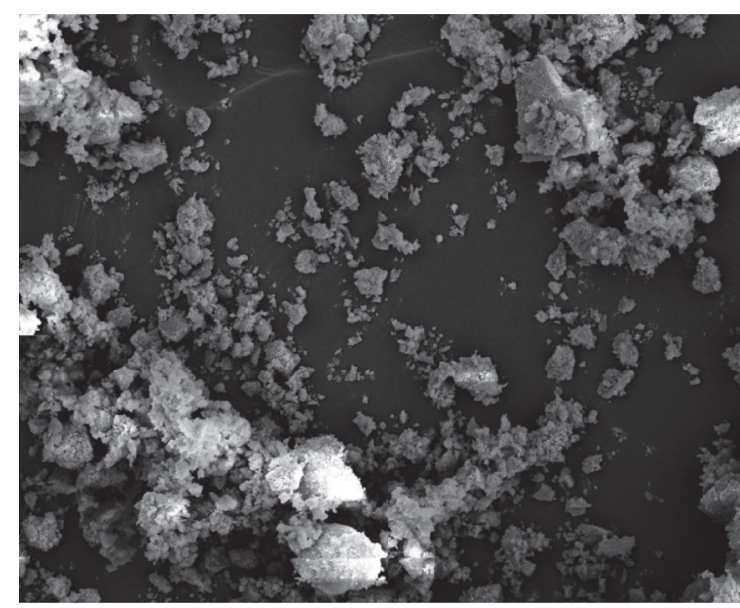

$100 \mu \mathrm{m}$

S1

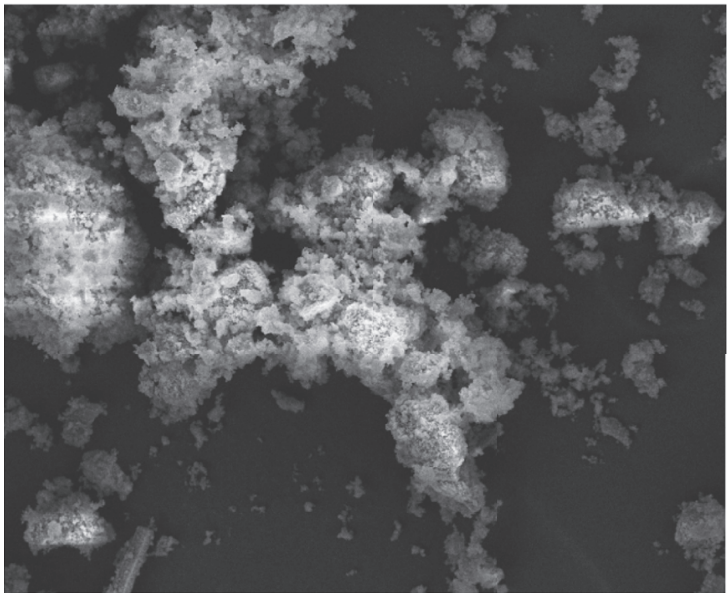

$100 \mu \mathrm{m}$

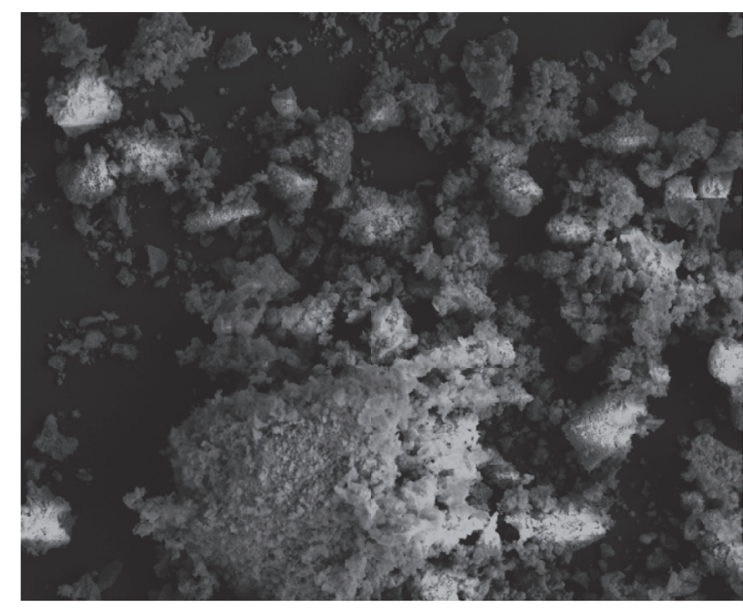

$100 \mu \mathrm{m}$

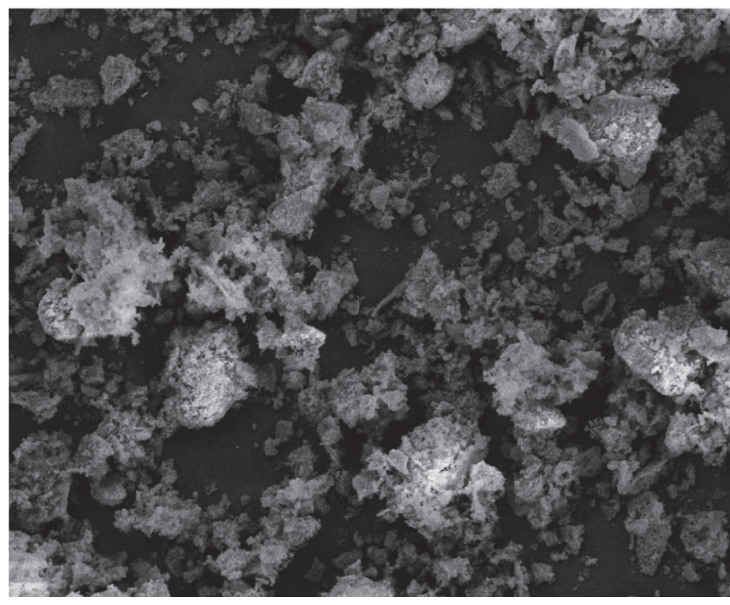

$100 \mu \mathrm{m}$

FIgURE 4: SEM images for S1, S4, S6, and S7 materials.

decomposition. In this temperature domain, the literature presents some studies regarding decomposition of benzene and toluene and compound into small fragments followed by further oxidation to $\mathrm{CO}_{2}$ and water $[42,43]$. After extraction of weight loss due to dye decomposition and the oxidation of phenyl groups to $\mathrm{CO}_{2}$ and water, the total amount of the second hydroxyl group capable of reacting reached $86 \%$ for S1, 77\% for S2, and for lower 30-60\% for S3-S8. In the case of S3-S8, the amount of second hydroxyl group capable of reacting is decreased by the presence of dye. The oxidation process in this domain takes place with the highest rate and the corresponding temperature is situated between 517 and $528^{\circ} \mathrm{C}$ ( Td max).

The oxidation process continues till $900^{\circ} \mathrm{C}$. In the temperature domain $25-900^{\circ} \mathrm{C}$, the weight loss is situated in the range of $1.5-7.8 \%$ and corresponds to the further oxidation of organic part at $\mathrm{CO}_{2}$. In the case of S3-S8, the weight loss was increased by the presence of dye (Table 2).

\section{Conclusions}

We synthesized new hybrid materials by the incorporation witch three different dyes, at different molar ratios using the hydrolytic sol-gel process. The new obtained hybrid materials (gels) were investigated by using UV-vis spectra, FT-IR, TG, SEM, and TEM methods. Based on the obtained UVvis spectra, we can conclude that the dyes had significant influence, indicating that $\mathrm{Cl}$ dye has a greater efficiency when applied to dye-sensitized solar cells (DSSC). By TEM and SEM microscopy, we can see that hybrids S1-S8 show good porosity, which indicates facile diffusion of redox mediators within the layer. This porosity is necessary and mandatory in the application in DSSC to obtain a good interaction with surface-bound dye (sensitizer).

TGA data indicates in case of samples S3 and S5 that adding dye increases the loss of mass, and also in case of samples S4 and S6 the addition of dye is lower and so the 


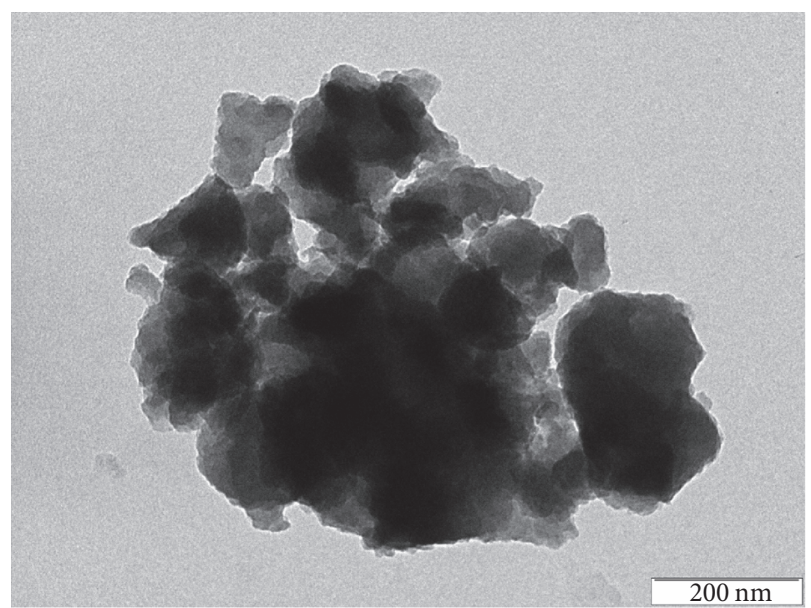

S1

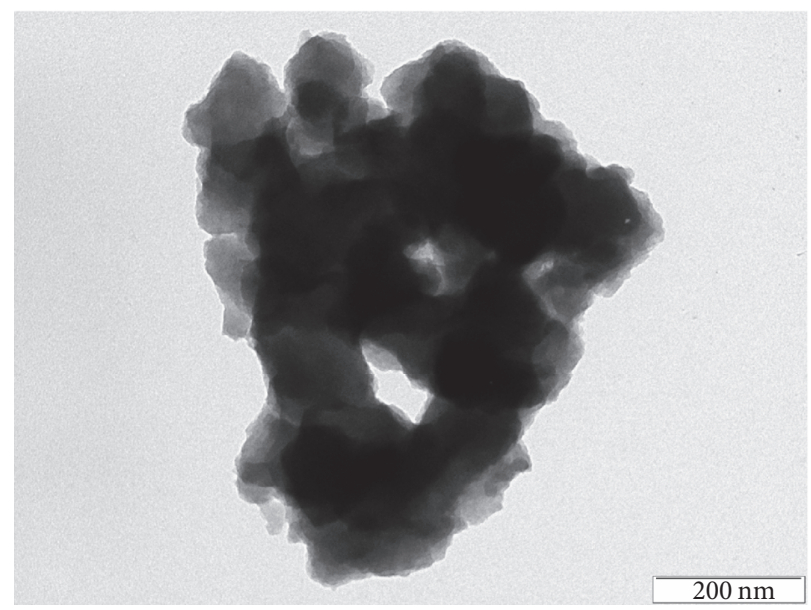

S3

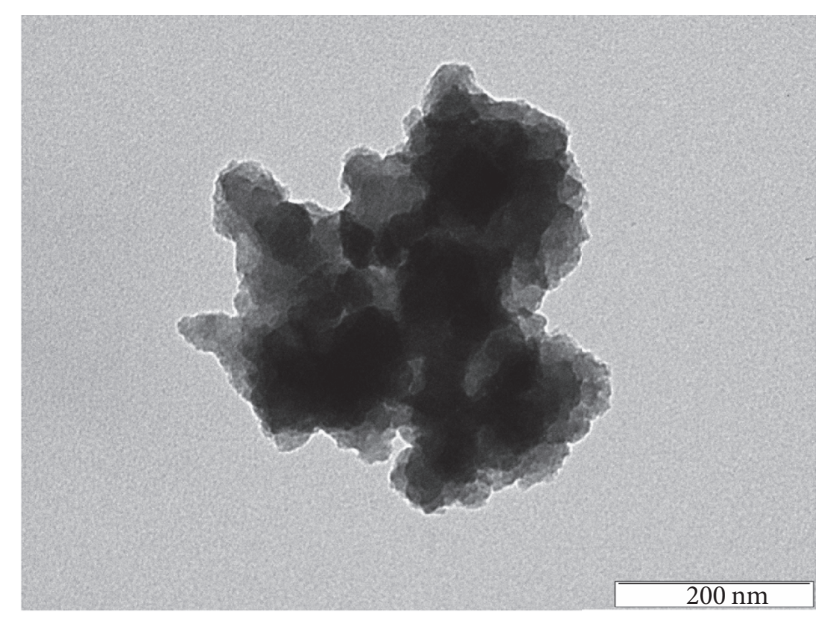

S2

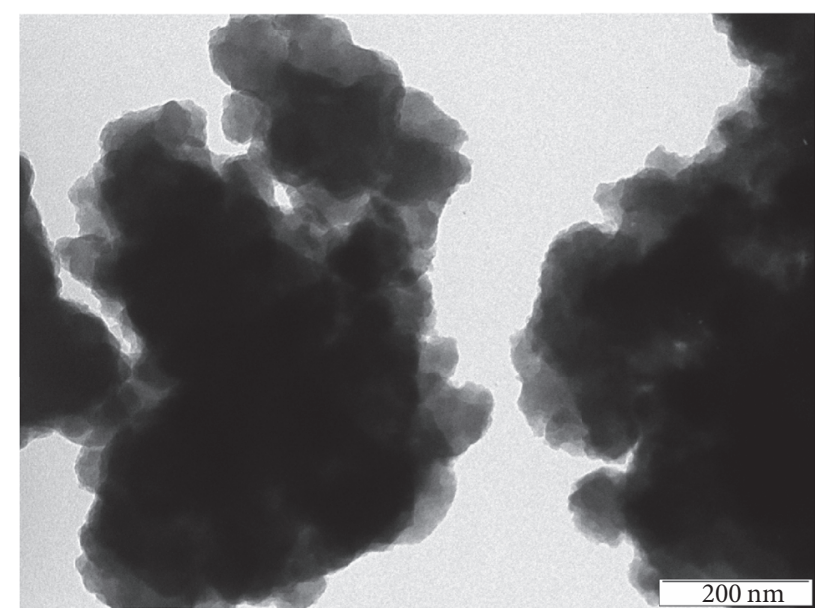

S8

FIGURE 5: TEM images for S1, S2, S3, and S8 materials.

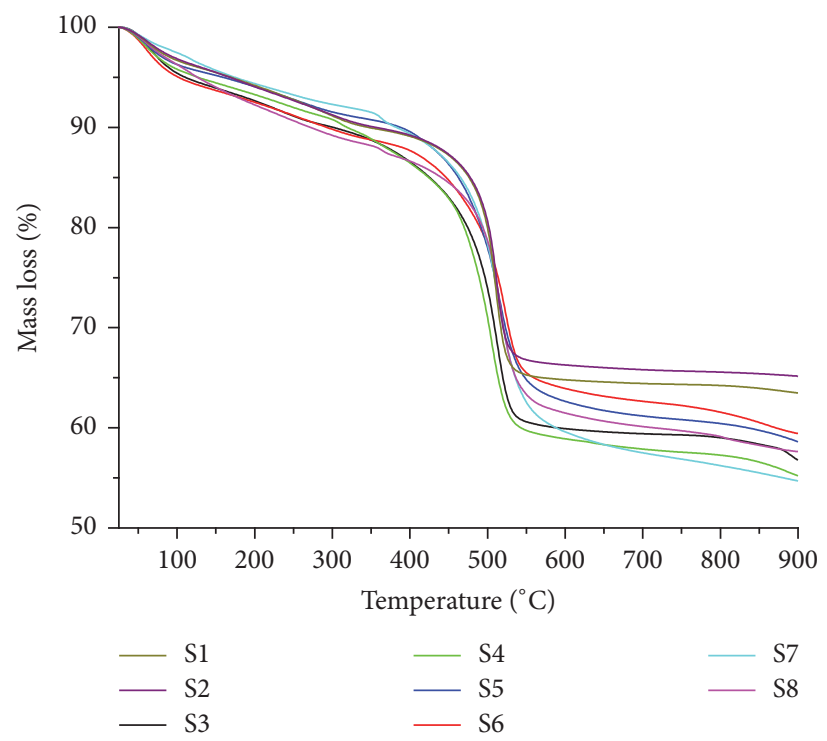

FIGURE 6: TG data for compounds S1-S8. 
TABLE 2: Weight loss of all compounds at different temperature ranges.

\begin{tabular}{|c|c|c|c|c|c|c|c|c|}
\hline & \multicolumn{5}{|c|}{ Weight loss, \% } & \multirow{2}{*}{ Residual at $900^{\circ} \mathrm{C}, \%$} & \multirow{2}{*}{$\mathrm{T} 5 \%,{ }^{\circ} \mathrm{C}$} & \multirow{2}{*}{$\mathrm{Td} \max ,{ }^{\circ} \mathrm{C}$} \\
\hline & $25-150^{\circ} \mathrm{C}$ & $150-350^{\circ} \mathrm{C}$ & $350-550^{\circ} \mathrm{C}$ & $550-900^{\circ} \mathrm{C}$ & $25-900^{\circ} \mathrm{C}$ & & & \\
\hline S1 & 4.516 & 5.537 & 24.667 & 1.796 & 36.516 & 63.484 & 170 & 522.59 \\
\hline S2 & 4.507 & 5.403 & 23.296 & 1.576 & 34.782 & 65.218 & 167 & 523.25 \\
\hline S3 & 6.070 & 5.192 & 28.133 & 3.792 & 43.187 & 56.813 & 110 & 519.52 \\
\hline S4 & 5.555 & 5.581 & 29.119 & 4.501 & 44.757 & 55.243 & 126 & 517.12 \\
\hline S5 & 4.812 & 4.423 & 25.951 & 6.173 & 41.360 & 58.640 & 160 & 525.78 \\
\hline S6 & 6.313 & 4.922 & 23.265 & 6.060 & 40.560 & 59.440 & 95 & 528.93 \\
\hline S7 & 4.303 & 4.194 & 28.943 & 7.850 & 45.290 & 54.710 & 175 & 523.41 \\
\hline S8 & 5.983 & 5.840 & 24.838 & 5.715 & 42.376 & 57.624 & 130 & 523.25 \\
\hline $\mathrm{C} 1$ & 8.464 & 13.959 & 40.759 & 5.312 & 68.495 & 31.505 & 87 & 476.67 \\
\hline $\mathrm{C} 2$ & 10.359 & 2.680 & 32.765 & 21.092 & 66.895 & 33.105 & 92 & 476.33 \\
\hline C3 & 5.059 & 3.474 & 19.510 & 42.577 & 70.621 & 29.379 & 136 & 783.21 \\
\hline
\end{tabular}

loss of mass is lower. All of these characteristics indicate the possible application of these films in solar cells. The transparent colored hybrid films have a very good optical quality with color intensity depending on the added amount of organic dye in the films. The dye incorporated gels leads to many applications as sensors, biosensors, solar concentrators for solar cells in the fields of photovoltaics, and so on.

\section{Conflicts of Interest}

The authors declare that there are no conflicts of interest regarding the publication of this article.

\section{Acknowledgments}

The authors acknowledge the Research Programme 2, Project 2.2, Institute of Chemistry Timisoara of the Romanian Academy.

\section{References}

[1] R. Reisfeld and C. K. Jorgensen, Chemistry, Spectroscopy and Applications of Sol-Gel Glasses, vol. 77, Springer, Berlin, Germany, 1992.

[2] R. Reisfeld, Lasers based in sol-gel technology, optical and electronic phenomena in sol-gel glasses and modern applications, structure and bonding, Springer, 1996.

[3] O. Wolfbeis and I. Reisfeld, Sol-Gel Sensors, Optical and Electronic Phenomena in Sol-Gel Glasses and Modern Applications, Structure and Bonding, Springer, 1996.

[4] R. Reisfeld, New materials for nonlinear optics, optical and electronic phenomena in sol-gel glasses and modern applications, structure and bonding, Springer, 1996.

[5] D. Avnir, D. Levy, and R. Reisfeld, "The nature of the silica cage as reflected by spectral changes and enhanced photostability of trapped rhodamine 6G," Journal of Physical Chemistry, vol. 88, no. 24, pp. 5956-5959, 1984.

[6] D. Avnir, V. R. Kaufman, and R. Reisfeld, "Organic fluorescent dyes trapped in silica and silica-titania thin films by the solgel method. Photophysical, film and cage properties," Journal of Non-Crystalline Solids, vol. 74, no. 2-3, pp. 395-406, 1985.
[7] J. D. Mackenzie and E. Bescher, "Some factors governing the coating of organic polymers by sol-gel derived hybrid materials," Journal of Sol-Gel Science and Technology, vol. 27, no. 1, pp. 7-14, 2003.

[8] R. Kasemann, "Coatings for mechanical and chemical protection based on organic-inorganic sol-gel nanocomposites," New J. Chem, vol. 18, pp. 1117-1123, 1994.

[9] C. Sanchez, F. Ribot, and B. Lebeau, "Molecular design of hybrid organic-inorganic nanocomposites synthesized via solgel chemistry," Journal of Materials Chemistry, vol. 9, no. 1, pp. 35-44, 1999.

[10] H. Schmidt, "Multifunctional inorganic-organic composite solgel coatings for glass surfaces," Journal of Non-Crystalline Solids, vol. 178, no. C, pp. 302-312, 1994.

[11] U. Schubert, N. Hüsing, and A. Lorenz, "Hybrid inorganicorganic materials by sol-gel processing of organofunctional metal alkoxides," Chemistry of Materials, vol. 7, no. 11, pp. 20102027, 1995.

[12] P. Judeinstein and C. Sanchez, "Hybrid organic-inorganic materials: a land of multidisciplinarity," Journal of Materials Chemistry, vol. 6, no. 4, pp. 511-525, 1996.

[13] H. Schmidt, "New type of non-crystalline solids between inorganic and organic materials," Journal of Non-Crystalline Solids, vol. 73, no. 1-3, pp. 681-691, 1985.

[14] A. Makishima and T. Tani, "Preparation of Amorphous Silicas Doped with Organic Molecules by the Sol-Gel Process," Journal of the American Ceramic Society, vol. 69, no. 4, pp. 72-74, 1986.

[15] J. C. Pouxviel, S. Parvaneh, E. T. Knobbe, and B. Dunn, "Interactions between organic dyes and sol-gel matrices," Solid State Ionics, vol. 32-33, no. 2, pp. 646-654, 1989.

[16] M. M. E. Severin-Vantilt and E. W. J. L. Oomen, "The incorporation of Rhodamine B in silica sol-gel layers," Journal of NonCrystalline Solids, vol. 159, no. 1-2, pp. 38-48, 1993.

[17] S. Shibata, T. Taniguchi, T. Yano, A. Yasumori, and M. Yamane, "Spherical dye-doped silica particles - Code: FP9," Journal of Sol-Gel Science and Technology, vol. 2, no. 1-3, pp. 755-759, 1994.

[18] J. Oh, H. Imai, and H. Hirashima, "Direct Deposition of Mesoscopically Assembled Dye-Doped Silica Films from Aqueous Solutions of Silicon Alkoxides," Chemistry of Materials, vol. 10, no. 6, pp. 1582-1588, 1998.

[19] H. Zollinger, Colour chemistry-synthesis, properties and applications of organic dyes and pigments, Wiley VCH, New York, NY, USA, 1987. 
[20] Č. Novotný, N. Dias, A. Kapanen et al., "Comparative use of bacterial, algal and protozoan tests to study toxicity of azo- and anthraquinone dyes," Chemosphere, vol. 63, no. 9, pp. 1436-1442, 2006.

[21] A. Hagfeldt, G. Boschloo, L. Sun, L. Kloo, and H. Pettersson, "Dye-sensitized solar cells," Chemical Reviews, vol. 110, no. 11, pp. 6595-6663, 2010.

[22] Y. Ooyama, T. Nagano, S. Inoue et al., "Dye-sensitized solar cells based on donor- $\pi$-acceptor fluorescent dyes with a pyridine ring as an electron-withdrawing-injecting anchoring group," Chemistry - A European Journal, vol. 17, no. 52, pp. 14837-14843, 2011.

[23] B. C. O’Regan, K. Walley, M. Juozapavicius et al., "Structure/ function relationships in dyes for solar energy conversion: a two-atom change in dye structure and the mechanism for its effect on cell voltage," Journal of the American Chemical Society, vol. 131, no. 10, pp. 3541-3548, 2009.

[24] M. L. Parisi, S. Maranghi, and R. Basosi, "The evolution of the dye sensitized solar cells from Grätzel prototype to up-scaled solar applications: a life cycle assessment approach," Renewable and Sustainable Energy Reviews, vol. 39, pp. 124-138, 2014.

[25] H. M. Upadhyaya, S. Senthilarasu, M.-H. Hsu, and D. K. Kumar, "Recent progress and the status of dye-sensitised solar cell (DSSC) technology with state-of-the-art conversion efficiencies," Solar Energy Materials and Solar Cells, vol. 119, pp. 291-295, 2013.

[26] M. L. Parisi, A. Sinicropi, and R. Basosi, "Life cycle assessment of gratzel-type cell production for non conventional photovoltaics from novel organic dyes," International Journal of Heat and Technology, vol. 29, no. 2, pp. 161-169, 2011.

[27] C. Maglione, A. Carella, C. Carbonara et al., "Novel pyran based dyes for application in dye sensitized solar cells," Dyes and Pigments, vol. 133, pp. 395-405, 2016.

[28] V. Simulescu, M. Kalina, J. Mondek, and M. Pekař, "Long-term degradation study of hyaluronic acid in aqueous solutions without protection against microorganisms," Carbohydrate Polymers, vol. 137, pp. 664-668, 2016.

[29] V. Simulescu, J. Mondek, M. Kalina, and M. Pekař, "Kinetics of long-term degradation of different molar mass hyaluronan solutions studied by SEC-MALLS," Polymer Degradation and Stability, vol. 111, pp. 257-262, 2015.

[30] J. Mondek, M. Kalina, V. Simulescu, and M. Pekař, “Thermal degradation of high molar mass hyaluronan in solution and in powder; comparison with BSA," Polymer Degradation and Stability, vol. 120, article 7680, pp. 107-113, 2015.

[31] M. Drehe, V. Simulescu, and G. Ilia, "Progress in the development of flame retardants," Reviews in Chemical Engineering, vol. 24, no. 6, pp. 263-302, 2008.

[32] T.-Z. Ren, Z.-Y. Yuan, and B.-L. Su, "Surfactant-assisted preparation of hollow microspheres of mesoporous TiO2," Chemical Physics Letters, vol. 374, no. 1-2, pp. 170-175, 2003.

[33] B. Bujoli, P. Palvadeau, and M. Queignec, "Synthesis characterization and amine intercalation behavior of $\mathrm{Zn}$ phosphite phenylphosphonate mixed derivatives," Eur. J. Solid State Inorg. Chem, vol. 29, pp. 141-159, 1992.

[34] L. C. Thomas, The identification of functional groups in organophosphorus compounds, Academic Press, New York, NY, USA, 1974.

[35] W. Gao, L. Dickinson, C. Grozinger, F. G. Morin, and L. Reven, "Self-assembled monolayers of alkylphosphonic acids on metal oxides," Langmuir, vol. 12, no. 26, pp. 6429-6435, 1996.
[36] M. Giza, P. Thissen, and G. Grundmeier, "Adsorption kinetics of organophosphonic acids on plasma-modified oxide-covered aluminum surfaces," Langmuir, vol. 24, no. 16, pp. 8688-8694, 2008.

[37] G. Guerrero, P. H. Mutin, and A. Vioux, "Anchoring of phosphonate and phosphinate coupling molecules on titania particles," Chemistry of Materials, vol. 13, no. 11, pp. 4367-4373, 2001.

[38] F. Odobel, B. Bujoli, and D. Massiot, "Zirconium phosphonate frameworks covalently pillared with a bipyridine moiety," Chemistry of Materials, vol. 13, no. 1, pp. 163-173, 2001.

[39] R. M. Almeida and J. D. Mackenzie, "Infrared absorption and structure of chlorophosphate glasses," Journal of Non-Crystalline Solids, vol. 40, no. 1-3, pp. 535-548, 1980.

[40] X.-J. Zhang, T.-Y. Ma, and Z.-Y. Yuan, "Nanostructured titaniadiphosphonate hybrid materials with a porous hierarchy," European Journal of Inorganic Chemistry, no. 17, pp. 2721-2726, 2008.

[41] N. Misra, A. Dwivedi, and A. Kumar Pandey, "Structural, vibrational and electronic properties of small group IV oxide clusters in lower and higher spin state: a DFT study," Journal of Atomic and Molecular Sciences, vol. 3, no. 3, pp. 187-196, 2012.

[42] J. Mizuguchi and T. Shinbara, "Disposal of used optical disks utilizing thermally-excited holes in titanium dioxide at high temperatures: a complete decomposition of polycarbonate," Journal of Applied Physics, vol. 96, no. 6, pp. 3514-3519, 2004.

[43] T. Marino, K. Matsumoto, T. Ebara, T. Mine, T. Ohtsuka, and J. Mizuguchi, "Complete decomposition of benzene, toluene, and particulate matter contained in the exhaust of diesel engines by means of thermally excited holes in titanium dioxide at high temperatures," Japanese Journal of Applied Physics, Part 1: Regular Papers and Short Notes and Review Papers, vol. 46, no. 9A, pp. 6037-6042, 2007. 

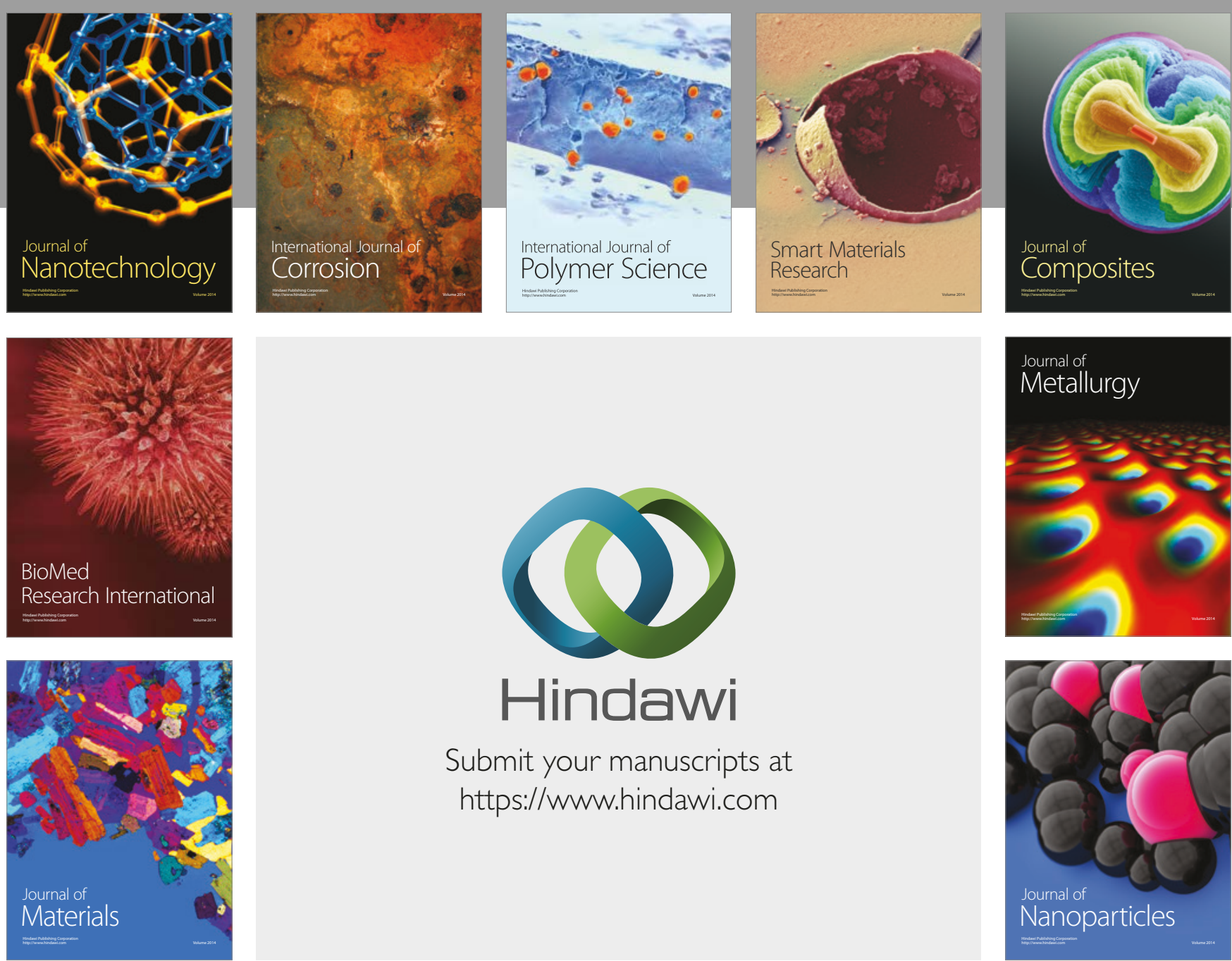

\section{Hindawi}

Submit your manuscripts at

https://www.hindawi.com
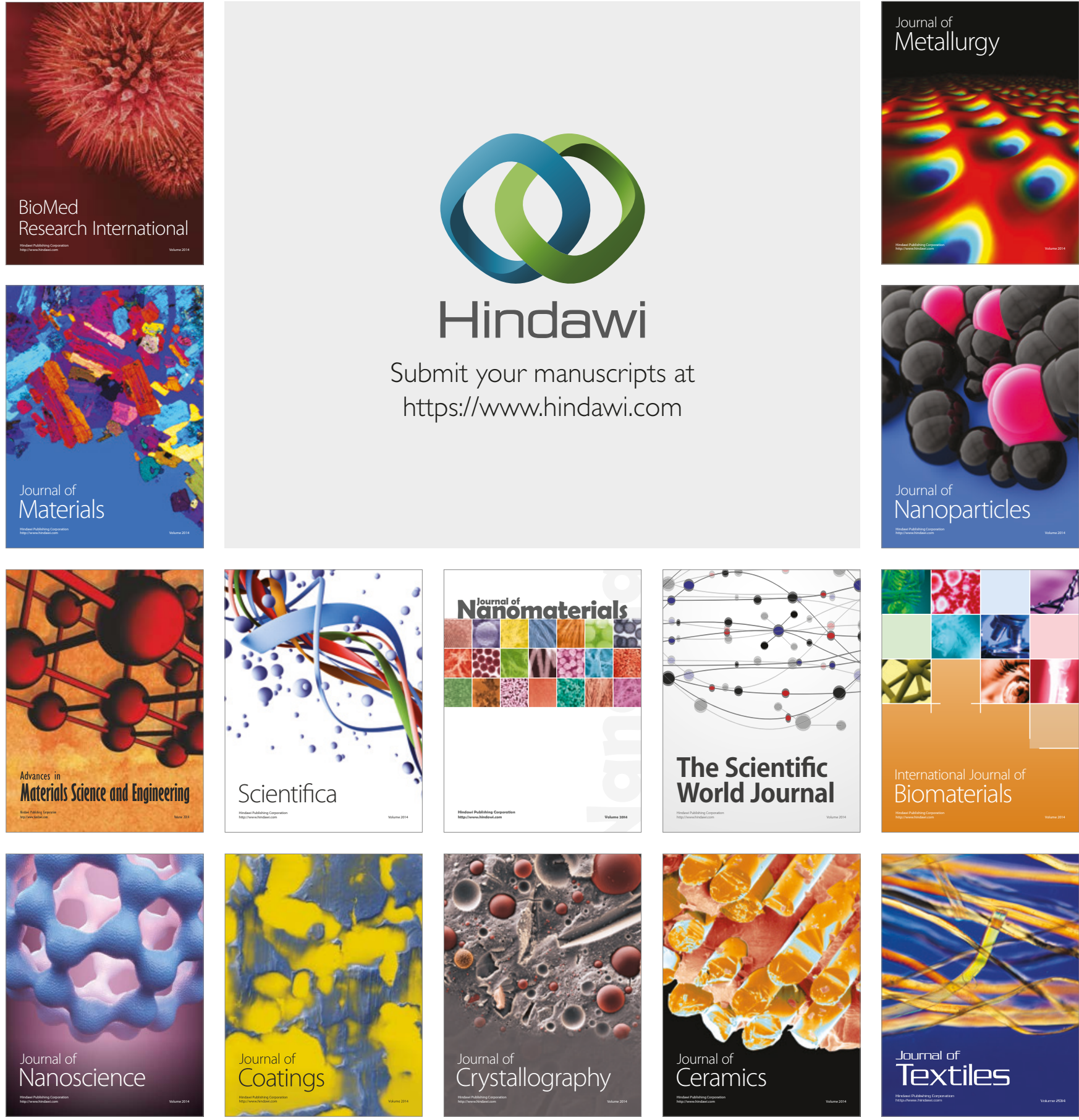

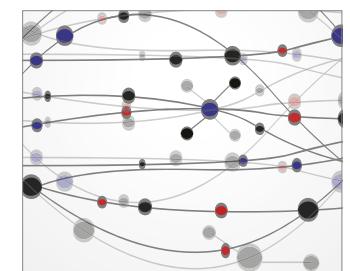

The Scientific World Journal
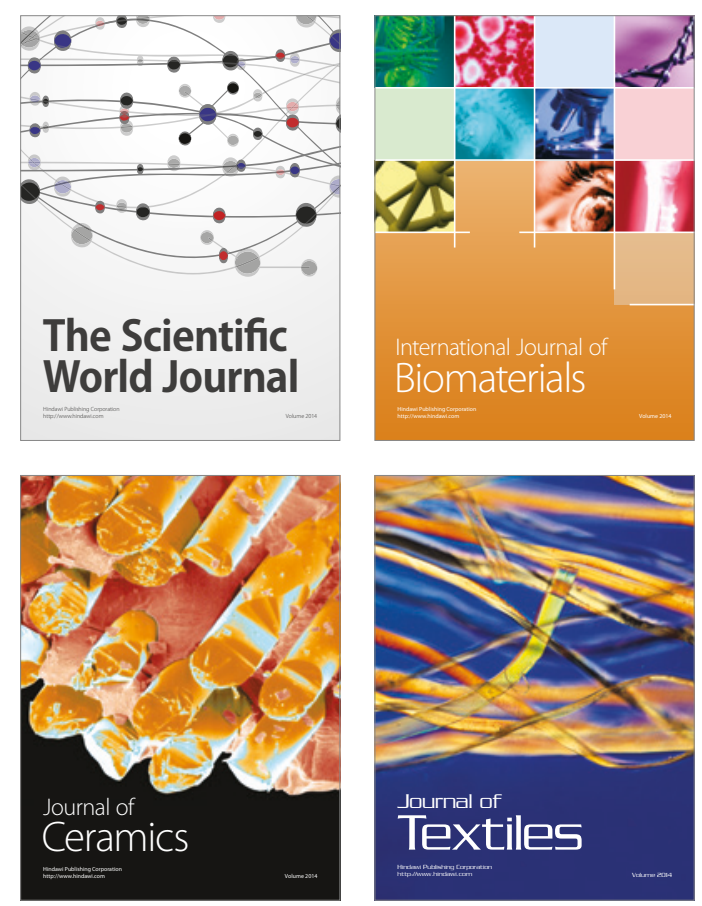